\title{
In Vivo Dilation of Fetal and Neonatal Ductus Arteriosus by Inhibition of Phosphodiesterase-5 in Rats
}

\author{
KAZUO MOMMA, KATSUAKI TOYOSHIMA, SHINICHIRO IMAMURA, AND \\ TOSHIO NAKANISHI \\ Department of Pediatric Cardiology [K.M., K.T., S.I., T.N.], Tokyo Women's Medical University, Tokyo \\ 162-8666, Japan; and Department of Neonatology [K.T.], Kanagawa Children's Medical Center, \\ Yokohama 232-8555, Japan
}

\begin{abstract}
A recent in vitro study showed that sildenafil, a type 5 phosphodiesterase inhibitor, dilated the constricted ductus arteriosus of neonatal rabbits. We studied the in vivo ductus-dilating effects of sildenafil in fetal and neonatal rats. Ductus diameters were measured with whole-body freezing and cutting on a freezing microtome. Indomethacin $(10 \mathrm{mg} / \mathrm{kg})$ constricted the fetal ductus severely at 4 and $8 \mathrm{~h}$ after orogastric administration to the dams. Sildenafil, administered orogastrically and simultaneously with indomethacin, dilated the near-term fetal [21 fetal days (FD)] ductus constricted by indomethacin completely with 1 $\mathrm{mg} / \mathrm{kg}$ at $8 \mathrm{~h}$ after administration. The preterm fetal ductus was more sensitive to sildenafil at 19FD. The ductus constricted rapidly after birth, and the ductal diameter was only $10 \%$ of the fetal diameter at $1 \mathrm{~h}$ after birth. The ductus-dilating effect of sildenafil was studied by i.p. injection at $1 \mathrm{~h}$ after birth, and the ductus diameter was studied 30 and 60 min later. Sildenafil dilated the neonatal constricted ductus moderately with a mas-
\end{abstract}

\section{ABSTRACT}

sive dose $(100 \mathrm{mg} / \mathrm{kg})$ and only minimally with $1 \mathrm{mg} / \mathrm{kg}$. In conclusion, sildenafil, a type 5 phosphodiesterase inhibitor, dilated the constricted fetal ductus completely at $8 \mathrm{~h}$ with $1 \mathrm{mg} / \mathrm{kg}$ in the near-term fetus and completely with a smaller dose $(0.1$ $\mathrm{mg} / \mathrm{kg}$ ) in the preterm fetus. However, sildenafil dilated the neonatal constricted ductus only moderately with large doses and minimally with $1 \mathrm{mg} / \mathrm{kg}$. Probably, sildenafil is useful clinically for treating idiopathic and secondary fetal ductal constriction and not useful for dilation of the neonatal constricted ductus. (Pediatr Res 58: 42-45, 2005)
DA, ductus arteriosus
FD, fetal day
NO, nitric oxide
PDE, phosphodiesterase
PGE, prostaglandin E

Abbreviations
The ductus arteriosus (DA) is widely patent in the fetus and constricts soon after birth (1-3). In neonates with certain congenital heart diseases, including pulmonary atresia and aortic atresia, patency of the DA is essential for survival (4), and prostaglandin E (PGE) is used to dilate the constricted DA (5). Physiologically, PGE and nitric oxide (NO) work to dilate the fetal DA $(6,7)$, and these work through an increase in cAMP and cGMP, respectively, as intracellular second messengers in ductal smooth muscle cells (8). cGMP is degraded by phosphodiesterase (PDE)-5 (9). PDE-5 inhibitors, including sildenafil, have been developed and applied for erectile dysfunction (10). A recent study by Thebaud et al. (11) showed ductal dilation and increased cGMP in ductal tissue by silde-

Received April 20, 2004; accepted October 13, 2004.

Correspondence: Kazuo Momma, M.D., Department of Pediatric Cardiology, Tokyo Women's Medical University. Kawadacho, Shinjuku-ku, Tokyo 162-8666. Japan; e-mail: prmomma@hij.twmu.ac.jp.

Supported by a grant from the Japanese Promotion Society for Cardiovascular Disease.

DOI: 10.1203/01.PDR.0000156370.50874.3C nafil in a rabbit in vitro study. We hypothesized that inhibition of type 5 PDE can increase cGMP and dilate the fetal and neonatal DA in vivo. Here we report in vivo DA dilation by sildenafil in fetal and neonatal rats.

\section{METHODS}

Animals. Virgin Wistar rats (pregnancy period $21.5 \mathrm{~d}$ ) were mated overnight from 1700 to $0900 \mathrm{~h}$; the presence of sperm in vaginal smears fixed day 0 of pregnancy. Rats were housed in an environmentally controlled room, acclimatized to a 12:12-h light/dark cycle, and maintained on commercial solid food and tap water ad libitum. Treatment conformed to the guiding principles of the American Physiologic Society. The experiment was approved by the Ethical Committee of Animal Experiments of our institute. Experiments were done either in the near-term fetus and neonate on the 21st gestational day or in the preterm fetus on the 19th gestational day. These experimental designs are illustrated in Table 1.

Drugs. Sildenafil citrate (Pfizer, New York, NY) was prepared by crushing a 50-mg tablet to powder. It was administered to the dam through an orogastric tube with $2 \mathrm{~mL}$ of water. To the neonate, it was dissolved in $0.05 \mathrm{~mL}$ of DMSO and injected i.p.

Fetal studies. We studied 170 near-term fetuses from 16 dams. The following fetal studies were done using one or two pregnant rats for each drug, dose, and time. The dilating effects of sildenafil citrate (11) (100, 10, or 1 
Table 1. Developmental stages of the rats, methods of ductal constriction, route of administration and doses of sildenafil, and times of study after administration in this study

\begin{tabular}{lccl}
\hline \multicolumn{1}{c}{ Stage } & Fetus (D19) & Fetus (D21) & \multicolumn{1}{c}{ Neonate $(1 \mathrm{~h})$} \\
\hline DA constriction & $\begin{array}{c}\text { Indomethacin } \\
(10 \mathrm{mg} / \mathrm{kg}) \\
\text { orogastric } \\
\text { to dams }\end{array}$ & $\begin{array}{c}\text { Indomethacin } \\
(10 \mathrm{mg} / \mathrm{kg}) \\
\text { orogastric } \\
\text { to dams }\end{array}$ & $\begin{array}{c}\text { Birth-related event; } \\
\text { incubated in room } \\
\text { air at } 34^{\circ} \mathrm{C}\end{array}$ \\
$\begin{array}{c}\text { Sildenafil } \\
\text { Route } \\
\text { Dose (mg/kg) }\end{array}$ & $\begin{array}{l}\text { Transplacental } \\
\text { Transplacental }\end{array}$ & $\begin{array}{l}\text { T.p. injection } \\
0.01,0.1,1, \\
\text { and } 10\end{array}$ & $\begin{array}{l}1,10, \text { and } 100 \\
\text { Time of }\end{array}$ \\
study & $4 \mathrm{~h}, 8 \mathrm{~h}$ & $\begin{array}{l}\mathrm{h}, 8 \mathrm{~h} \\
0.5 \mathrm{~h}, 1 \mathrm{~h}\end{array}$ \\
\hline
\end{tabular}

$\mathrm{mg} / \mathrm{kg}$ ) in the fetal ductus were studied by simultaneous administration of sildenafil and indomethacin through an orogastric tube with $2 \mathrm{~mL}$ of water to the dam and by studying the DA at 4 and $8 \mathrm{~h}$ after administration. In addition, the dilating effect of sildenafil on the DA, ascending aorta, and main pulmonary artery without simultaneous administration of indomethacin was studied by orogastric administration of $10 \mathrm{mg} / \mathrm{kg}$ sildenafil and by examining the fetuses $8 \mathrm{~h}$ later. The mean body weight of the near-term fetus was $5.8 \mathrm{~g}$, and those $<5.0 \mathrm{~g}$ were discarded.

The DA-dilating effects of sildenafil were studied also in preterm fetus on fetal day 19 (19FD). We studied 120 preterm fetuses from 11 preterm dams. The dilating effects of sildenafil were studied by simultaneous administration of sildenafil and indomethacin through an orogastric tube with $2 \mathrm{~mL}$ of water to the dam and then by examining the DA at 4 and $8 \mathrm{~h}$ after administration. The mean body weight of the preterm fetus was $2.6 \mathrm{~g}$, and those whose body weight was $<2.2 \mathrm{~g}$ were discarded.

Neonatal studies. We studied 110 neonatal rats from 10 near-term dams. After atlas dislocation and cesarean section of the near-term rat, newborn rats were incubated in room air at $34^{\circ} \mathrm{C}$ for 90 or $120 \mathrm{~min}$. Neonatal DA dilation by sildenafil was studied with three doses $(100,10$, and $1 \mathrm{mg} / \mathrm{Kg})$, using $10-14$ neonates for each dose and time. Sildenafil citrate $(100,10$, or $1 \mathrm{mg} / \mathrm{kg})$ in 0.05 $\mathrm{mL}$ of DMSO was injected i.p. to the neonatal rat at $60 \mathrm{~min}$ after birth, the neonates were frozen, and the DA was studied 30 or 60 min after injection (at 90 or 120 min after birth).

Measurements. To study the in situ morphology of the fetal DA, we used a rapid whole-body freezing method as described in earlier studies $(12,13)$. Briefly, in the fetal studies, fetuses were delivered by cesarean section with atlas dislocation of the mother rat and frozen immediately in acetone cooled to $-80^{\circ} \mathrm{C}$ by dry ice. In the neonatal studies, the neonates were frozen 30 and 60 min after drug injection, and the frozen fetuses were weighed. Eight to 12 fetuses were studied from each litter. The frozen thorax was cut on a freezing microtome (Komatsu Solidate Co. Ltd., Tokyo, Japan) in the frontal plane, and the inner diameters of the ascending aorta, main pulmonary artery, and DA were measured every $100 \mu \mathrm{m}$ in $10-15$ planes with a microscope (Nikon Binocular Stereoscopic Microscope; Nihon Kogaku Co., Tokyo, Japan) and a micrometer (Nikon Ocular Micrometer; Nihon Kogaku Co.; Fig. 1). Constriction of the fetal DA was not uniform but most severe at the aortic end (14). The narrowest DA diameter was used as the indicator of constriction.

Photographs. The frontal section of the DA was photographed to demonstrate ductal constriction with a binocular stereoscopic microscope (Wild M400 Photomacroscope; Wild Heerbrugg Lid, Heerbrugg, Switzerland) using color film (Reale, Fuji Film Co., Tokyo, Japan; Fig. 1).

Statistics. The results are expressed as mean \pm SEM. The statistical significance of differences between group means was determined by ANOVA and the Bonferroni method (15). The difference was considered to be significant at $p<0.05$.

\section{RESULTS}

In these studies, maternal or neonatal death was not observed with sildenafil. After orogastric administration of 10 $\mathrm{mg} / \mathrm{kg}$ indomethacin to near-term (FD21) rats, the inner diameter of the DA was $0.80 \pm 0.03 \mathrm{~mm}$ (mean $\pm \mathrm{SEM}$ ) without the drug and $0.20 \pm 0.03$ and $0.16 \pm 0.02 \mathrm{~mm}$ at 4 and $8 \mathrm{~h}$, respectively, after administration of indomethacin (Fig. 2). After orogastric administration of $10 \mathrm{mg} / \mathrm{kg}$ indomethacin to

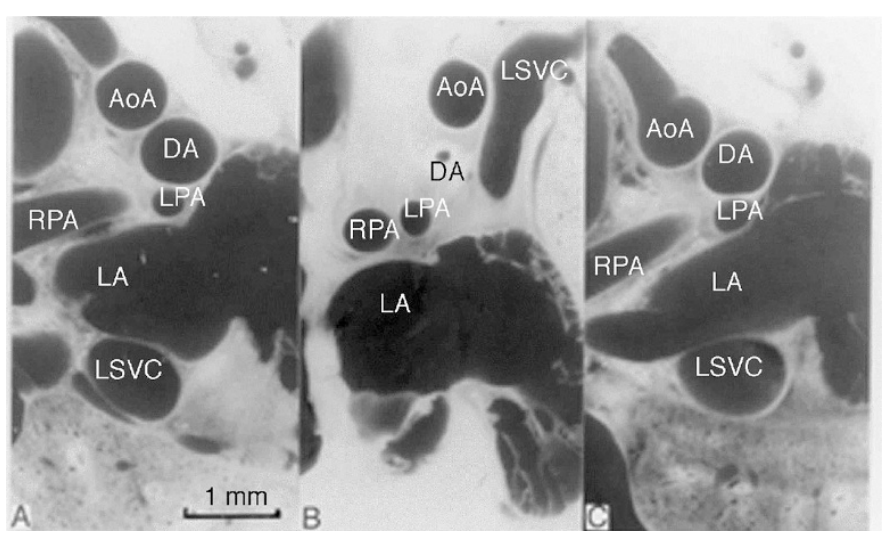

Figure 1. Photographs of the frontal section of the near-term (FD21) fetal DA. (A) Control DA without medication. The DA is dilated with an inner diameter of $0.8 \mathrm{~mm}$ and a thin wall. $(B)$ Constricted DA at $8 \mathrm{~h}$ with indomethacin $(10 \mathrm{mg} / \mathrm{kg})$. The DA is constricted with an inner diameter of 0.2 $\mathrm{mm}$ and a thick wall. $(C)$ Dilated DA at $8 \mathrm{~h}$ with sildenafil $(1 \mathrm{mg} / \mathrm{kg})$ and indomethacin $(10 \mathrm{mg} / \mathrm{kg})$. The DA is dilated with inner diameter $0.8 \mathrm{~mm}$ and a thin wall. AoA, aortic arch; LA, left atrium; LPA, left pulmonary artery; LSVC, left superior vena cava; RPA, right pulmonary artery.

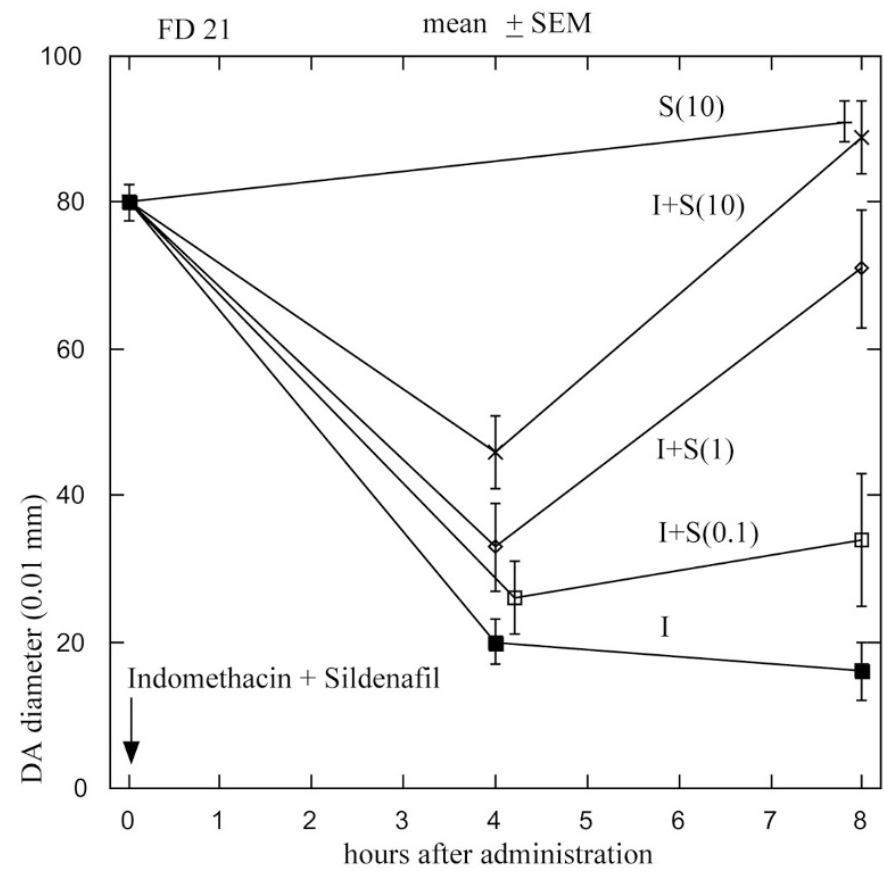

Figure 2. Dilation of the fetal DA constricted by indomethacin $(10 \mathrm{mg} / \mathrm{kg}$, orogastric) with simultaneously administered sildenafil ( $\mathrm{S}$; doses in $\mathrm{mg} / \mathrm{kg}$ ) in near-term rats. The $x$ axis shows time after administration of drugs in hours. The $Y$ axis shows the DA diameter in $0.01 \mathrm{~mm}$. Each value expressed as mean \pm SEM obtained from eight to 12 fetuses. The ductus was fully dilated, and its diameter was $0.71 \pm 0.08 \mathrm{~mm}[n=12$; statistically not significantly different from the initial diameter $(0.80 \pm 0.03 \mathrm{~mm}, n=24)$ at $8 \mathrm{~h}$ after administration of indomethacin and $1 \mathrm{mg} / \mathrm{kg}$ (clinical dose) sildenafil $(\mathrm{I}+\mathrm{S}(1))]$. I, indomethacin. Arrow indicates timing of drug administration.

preterm (FD19) rats, the inner diameter of the DA was $0.54 \pm$ $0.03 \mathrm{~mm}$ (mean $\pm \mathrm{SEM}$ ) without the drug and $0.38 \pm 0.03$ and $0.44 \pm 0.02 \mathrm{~mm}$ at 4 and $8 \mathrm{~h}$, respectively, after administration of indomethacin (Fig. 3). After delivery, the neonatal ductal inner diameter diminished from $0.80 \pm 0.03$ (at $0 \mathrm{~min}$ after birth) to $0.12 \pm 0.02,0.08 \pm 0.02,0.06 \pm 0.02$, and $0.02 \pm$ 


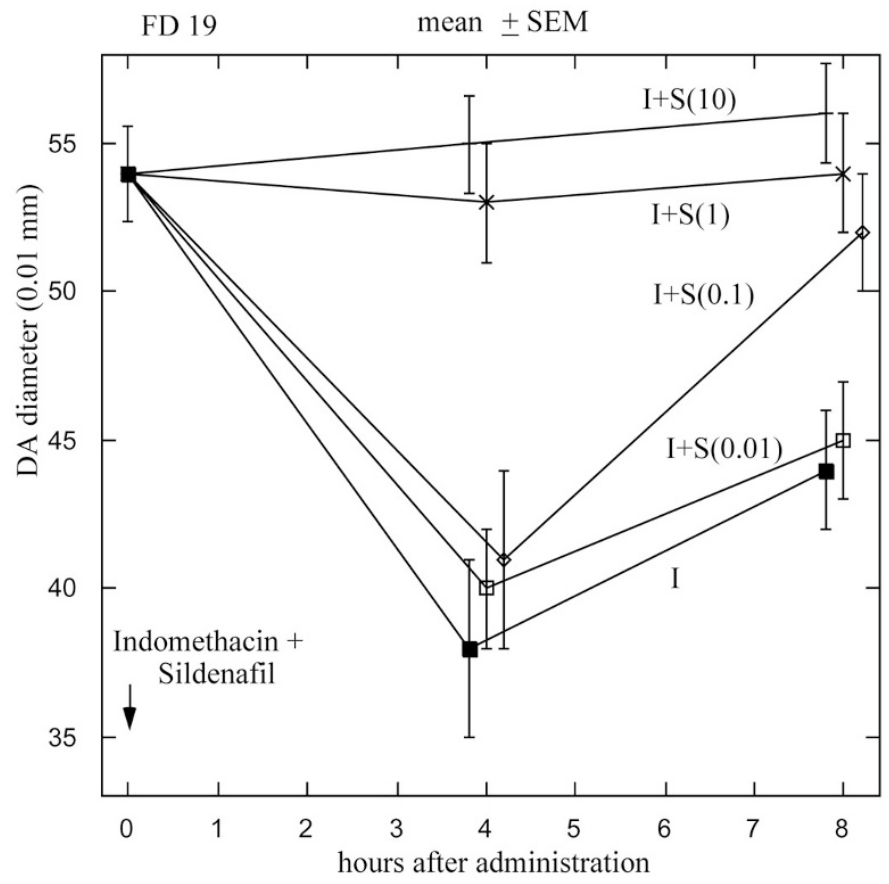

Figure 3. Dilation of the fetal DA constricted by indomethacin $(10 \mathrm{mg} / \mathrm{kg}$, orogastric) with simultaneously administered sildenafil (S; doses in $\mathrm{mg} / \mathrm{kg}$ ) in preterm rats (FD19). The $x$ axis shows the time after administration of drugs in hours. The $y$ axis shows the DA diameter in $0.01 \mathrm{~mm}$. At $8 \mathrm{~h}$ after administration of indomethacin and $0.1 \mathrm{mg} / \mathrm{kg}$ sildenafil, the DA diameter of the FD19 fetus was $0.52 \pm 0.02 \mathrm{~mm}(n=10)$, which was not significantly different from the initial diameter $(0.54 \pm 0.02 \mathrm{~mm} ; n=10)$.

$0.01 \mathrm{~mm}$ at $30,60,90$, and $120 \mathrm{~min}$ after birth, respectively (Fig. 4).

Sildenafil dilated the fetal DA at 21FD dose dependently (Fig. 2). Sildenafil $(10 \mathrm{mg} / \mathrm{kg})$ without indomethacin dilated the fetal DA, aorta, and pulmonary artery significantly, and the DA diameter was $0.91 \mathrm{~mm}$ (114\% of the control diameter) $8 \mathrm{~h}$ after administration (Table 2). The effects of sildenafil administered simultaneously with indomethacin were delayed, and more dilation was apparent $8 \mathrm{~h}$ after administration. A large dose $(10 \mathrm{mg} / \mathrm{kg})$ dilated the fetal DA completely, and the DA diameter was $0.89 \mathrm{~mm}(111 \%$ of the initial diameter) at $8 \mathrm{~h}$ after administration of sildenafil and indomethacin. A smaller dose $(1 \mathrm{mg} / \mathrm{kg})$ dilated the fetal DA almost completely at $8 \mathrm{~h}$ after administration, and the DA diameter was $71 \mathrm{~mm}(89 \%$ of the control diameter). Even a smaller dose $(0.1 \mathrm{mg} / \mathrm{kg})$ showed a small but significant dilation of the fetal DA $8 \mathrm{~h}$ after administration. The DA diameter was $0.34 \mathrm{~mm}$ and significantly larger than the DA diameter with indomethacin only $(0.16 \mathrm{~mm})$.

Sildenafil dilated the fetal DA at 19FD more effectively (Fig. $3)$. At $8 \mathrm{~h}$ after administration, even a very small dose $(0.1$ $\mathrm{mg} / \mathrm{kg}$ ) of sildenafil dilated the fetal DA almost completely, and the DA diameter was $0.52 \mathrm{~mm}(96 \%$ of the control diameter).

Neonatal DA was dilated by sildenafil dose dependently (Fig. 4). However, even a large dose $(100 \mathrm{mg} / \mathrm{kg})$ of sildenafil dilated the neonatal DA only moderately. The ductal diameter was $0.39 \mathrm{~mm}(49 \%$ of the control diameter $=0.80 \mathrm{~mm})$ at 30 min and $0.49 \mathrm{~mm}$ ( $61 \%$ of the control diameter) at $60 \mathrm{~min}$ after administration of $100 \mathrm{mg} / \mathrm{kg}$ sildenafil. The small dose $(1$ $\mathrm{mg} / \mathrm{kg}$ ) of the drug dilated the ductus mildly to $0.17 \mathrm{~mm}(21 \%$ of the control diameter) at $30 \mathrm{~min}$ after administration.

\section{DISCUSSION}

An earlier in vitro study by Thebaud et al. (11) showed that inhibition of type 5 PDE by sildenafil dilates rabbit DA constricted by oxygen, and our study has confirmed this finding in an in vivo study. They suggested that sildenafil might be clinically applied to dilate the DA in neonates with ductusdependent congenital heart diseases. Our study disclosed several new aspects of DA dilation by sildenafil in the fetal and the neonatal DA, which will be important for clinical application.

First, dilation of the neonatal DA by sildenafil is not marked; only moderate dilation occurred with large doses, and minimal dilation occurred with $1 \mathrm{mg} / \mathrm{kg}$, suggesting that the isolated use of sildenafil is not indicated clinically for DA dilation. In human neonates with congenital heart disease, the DA is dilated fully with continuous i.v. infusion of $100 \mathrm{ng} \cdot \mathrm{kg}^{-1} \cdot \mathrm{min}^{-1}$ PGE. Comparable data with continuous i.v. administration are not available in rat neonates, and it is difficult to compare the ductusdilating effect of sildenafil to PGE. Sildenafil has a longer in vivo half-life than PGE, and a large dose dilated the neonatal ductus only modestly, suggesting that the neonatal ductus-dilating effect of sildenafil is weaker than PGE.

Second, sildenafil dilated the fetal DA constricted by indomethacin at $8 \mathrm{~h}$ very effectively. Transplacental transfer of

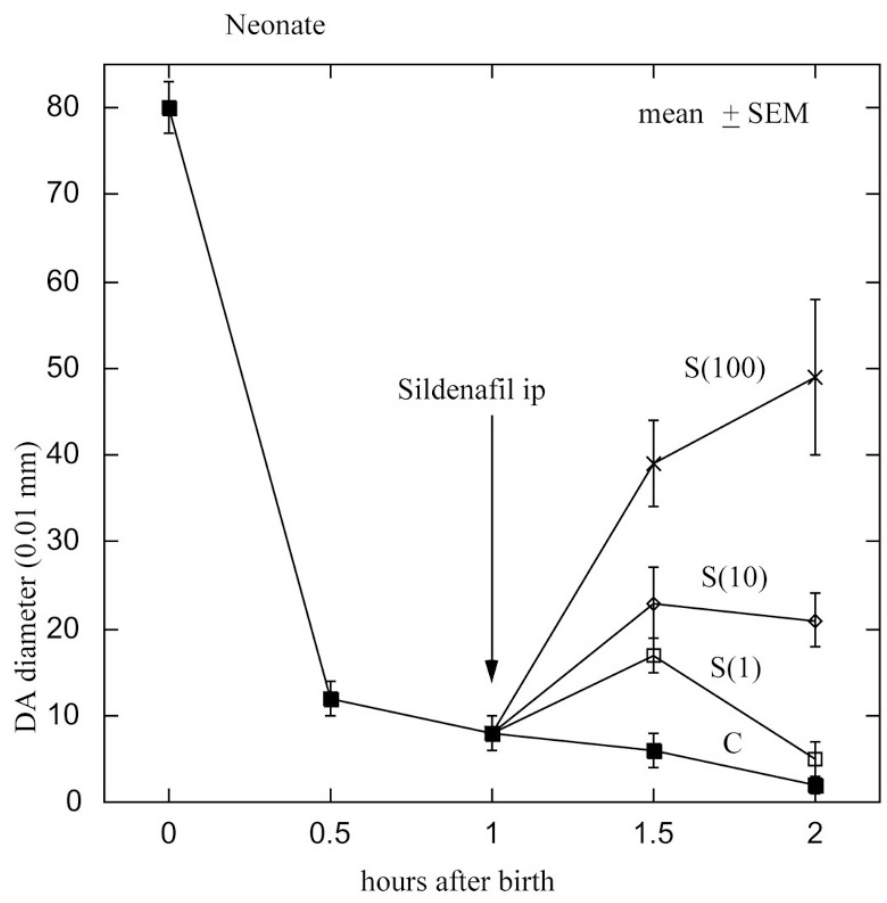

Figure 4. Dilation of the neonatal constricted DA by sildenafil (i.p. S; doses in $\mathrm{mg} / \mathrm{kg}$ ) injected at $60 \mathrm{~min}$ and studied at 90 and $120 \mathrm{~min}$ after birth. The $x$ axis shows the time after birth in hours. The $y$ axis shows the DA diameter in $0.01 \mathrm{~mm}$. At $1 \mathrm{~h}$ after administration of a large dose $(100 \mathrm{mg} / \mathrm{kg})$ of sildenafil to a 1-h-old neonatal rat, the DA dilated moderately and its diameter increased from $0.08 \pm 0.02 \mathrm{~mm}(n=14)$ to $0.49 \pm 0.09(n=14)$. A smaller dose of sildenafil $(1 \mathrm{mg} / \mathrm{kg})$ dilated the DA mildly at $30 \mathrm{~min}$ after administration, and the DA diameter was $0.17 \pm 0.02 \mathrm{~mm}(n=11)$ and significantly larger than the control $(0.06 \pm 0.01 \mathrm{~mm} ; n=11)$. C, control. 
Table 2. Vasodilation of the DA, the main pulmonary artery, and the ascending aorta 8 hours after orogastric administration of sildenafil $(10 \mathrm{mg} / \mathrm{kg})$ to the near-term dam on FD21

\begin{tabular}{|c|c|c|c|c|c|}
\hline & $\begin{array}{l}\text { No. of } \\
\text { fetuses }\end{array}$ & $\begin{array}{l}\text { Body weight } \\
(\mathrm{g})\end{array}$ & $\begin{array}{c}\text { DA } \\
(0.01 \mathrm{~mm})\end{array}$ & $\begin{array}{l}\text { Main pulmonary } \\
\text { artery }(0.01 \mathrm{~mm})\end{array}$ & $\begin{array}{c}\text { Ascending aorta } \\
(0.01 \mathrm{~mm})\end{array}$ \\
\hline Control & 10 & $5.9 \pm 0.2$ & $80 \pm 3$ & $79 \pm 2$ & $78 \pm 2$ \\
\hline Sildenafil & 10 & $6.1 \pm 0.2$ & $91 \pm 2^{*}$ & $94 \pm 2 *$ & $87 \pm 2^{*}$ \\
\hline
\end{tabular}

Vascular inner diameters are expressed in $0.01 \mathrm{~mm}$ and mean \pm SEM.

$* p<0.05$ vs control.

indomethacin to the fetus is rapid, and with this large dose, the fetal indomethacin concentration increases rapidly within $4 \mathrm{~h}$ after administration (14). Data on the transplacental transfer of sildenafil are not available, but the results of our study suggest a relatively later transfer of sildenafil to the fetus compared with indomethacin. Even a very small dose of sildenafil can dilate the fetal constricted DA, and the dilating effect is more prominent in the preterm fetus than in the near-term fetus. In fetal ductal constriction induced by indomethacin for tocolysis, ductal constriction usually disappears after the administration of indomethacin is stopped. However, in small fetuses with immature pulmonary function, sildenafil may be used to treat fetal ductal constriction.

The safety of sildenafil in male adults with several clinical problems, including heart failure, has been well confirmed $(16,17)$. The safety of sildenafil in female adults with pulmonary hypertension has been reported $(18,19)$, but the safety of the drug in late pregnancy remains to be studied.

Third, sildenafil dilated the fetal DA constricted by indomethacin more sensitively in preterm than in near-term rats. The reason for this phenomenon is not clear, but we speculate that it may be related to the changing mechanisms of fetal DA dilation in late gestation (7). It has been shown that in preterm fetal rats, the DA is dilated mainly by NO, and in near-term fetal rats, it is dilated mainly by prostaglandins (7). This is why the preterm fetal DA constricts only mildly with a large dose of indomethacin. Sildenafil inhibits type 5 PDE, increases cGMP in smooth muscle cell, and potentiates the effects of NO $(19,20)$. Probably this mechanism explains why sildenafil dilates the preterm constricted DA more potently.

To our disappointment, a very large dose of sildenafil was needed to dilate the neonatal constricted DA, and only minimal dilation of neonatal DA was obtained with $1 \mathrm{mg} / \mathrm{kg}$ sildenafil. Probably, inhibition of type 5 PDE is clinically applicable to dilate the fetal DA but not the neonatal DA.

We speculate on the high doses required to dilate the DA in the newborn rat as follows. In our ongoing studies on type 3 PDE inhibitors and the DA, type 3 PDE inhibitors dilated the fetal DA constricted with transplacental indomethacin at small doses, but larger doses were needed to dilate the neonatal constricted DA (unpublished data). Very probably, the birthrelated constricting stimuli to the neonatal DA including oxygen are so powerful that many more doses of vasodilating agents are needed to dilate the neonatal constricted DA than in fetal DA constricted by indomethacin.
Other reports suggest combined roles for prostaglandins and NO synthesis as ductus dilation (7). Type 5 PDE inhibition augments the effects of NO (20), and type 3 PDE inhibition augments the effect of prostaglandins (9). In our ongoing study of type 3 PDE inhibition, several type 3 PDE inhibitors, including amrinone and milrinone, dilated the fetal and neonatal constricted DA, and these results will be reported.

Acknowledgments. Editorial help of Barbara Levene and Leonard M. Linde, M.D., Professor of Pediatric Cardiology, University of Southern California, School of Medicine, is highly appreciated.

\section{REFERENCES}

1. Rudolph AM 2001 Congenital Diseases of the Heart, 2nd Ed. Futura, Armonk, pp 155-196

2. Rudolph AM 2003 Fetal circulation. In: Yagel S, Silverman NH, Gembruch U (eds) Fetal Cardiology. Martin Dunitz, London, pp 107-120

3. Momma K 2004 Fetal and neonatal ductus arteriosus. In: Curtis-Prior P (ed) The Eicosanoids. John Wiley \& Sons, Chichester, pp 569-581

4. Moor P, Brook MM, Heymann MA 2001 Patent ductus arteriosus. In: Allen HD, Gutgesell HP, Clark EB, Driscoll DJ (eds) Moss Adams Heart Disease in Infants, Children, and Adolescents, 6th Ed. Lippincott Williams \& Wilkins, Philadelphia, pp 652-669

5. Corbert AJ 1998 Medical manipulation of the ductus arteriosus. In: Garson A Jr, Bricker JT, Fisher DJ, Neish SR (eds) The Science and Practice of Pediatric Cardiology, 2nd Ed. Williams \& Wilkins, Baltimore, pp 2489-2513

6. Clyman RI 1990 Developmental physiology of the ductus arteriosus. In: Long WA (eds) Fetal \& Neonatal Cardiology. Saunders, Philadelphia, pp 64-75

7. Momma K, Toyono M 1999 The role of nitric oxide in dilating the fetal ductus arteriosus in rats. Pediatr Res 46:311-315

8. Walsh RS, Mentzer RM Jr 1987 Role of cyclic nucleotides in relaxation of fetal lamb ductus arteriosus. Surgery 102: 313-318

9. Beavo JA 1995 Cyclic nucleotide phosphodiesterases: functional implications of multiple isoforms. Physiol Rev 75:725-748

10. Jackson G, Benjamin N, Jackson N, Allen MJ 1999 Effects of sildenafil citrate on human hemodynamics. Am J Cardiol 83:13C-20C

11. Thebaud B, Michelakis E, Wu XC, Harry G, Hashimoto K, Archer SL 2002 Sildenafil reverses $\mathrm{O}_{2}$ constriction of the rabbit ductus arteriosus by inhibiting type 5 phosphodiesterase and activating BKca channels. Pediatr Res 52:19-24

12. Momma K, Nakanishi T, Imamura S 2003 Inhibition of in vivo constriction of fetal ductus arteriosus by endothelin receptor blockade in rats. Pediatr Res 53:479-485

13. Momma K, Nishihara S, Ota Y 1981 Constriction of the fetal ductus arteriosus by glucocorticoid hormones. Pediatr Res 15:19-21

14. Momma K, Konishi T, Hagiwara H 1985 Characteristic morphology of the constricted fetal ducts arteriosus following maternal administration of indomethacin. Pediatr Res 19:493-500

15. Wallenstein S, Zucker CL, Fleiss JL 1980 Some statistical methods useful in circulation research. Circ Res 47:1-9

16. Zusman RM 1999 Cardiovascular data on sildenafil citrate. Introduction. Am J Cardiol 83:1C-2C

17. Gillies HC, Roblin D, Jackson G 2002 Coronary and systemic hemodynamic effects of sildenafil citrate: from basic science to clinical studies in patients with cardiovascular disease. Int J Cardiol 86:131-141

18. Michelakis E, Tymchak W, Lien D, Webster L, Hashimoto K, Archer S 2002 Oral sildenafil is an effective and specific pulmonary vasodilator in patients with pulmonary artery hypertension: comparison with inhaled nitric oxide. Circulation 105:2398-2403

19. Wallis RM 1999 The pharmacology of sildenafil, a novel and selective inhibitor of phosphodiesterase (PDE) type 5. Nippon Yakurigaku Zasshi 114(suppl 1):22p-26p

20. Rybalkin SD, Yan C, Bornfeldt KE, Beavo JA 2003 Cyclic GMP phosphodiesterases and regulation of smooth muscle function. Circ Res 93:280-291 